\title{
8
}

\section{Songs for Distance, Dancing to Be Connected: Bonding Memories of the Ogasawara Islands}

\author{
Masaya Shishikura
}

\section{Introduction}

Farewelling is a ritual practice for departure and parting, as well as wishes for future reunion and affirmation of bonds after separation. Such a farewell ritual is habitual in a small island community of Ogasawara, Japan. For instance, a farewell is performed at every departure of the liner boat, Ogasawara Maru. Sasaki Hitoshi, owner of the Ogasawara Youth Hostel, sends off passengers by waving a flag (Figure 1). The flag has the word itterasshai printed on it that translates to 'see you soon', rather than sayonara or 'goodbye', in the hope that the people will soon return to Ogasawara. ${ }^{1}$ Another phrase mata miruyo, can also be heard at the port during the farewell ritual. 'European descendants' of Ogasawara began to use this phrase, which is a literal translation from an English phrase 'see you again'. The words mata miruyo are not a standard Japanese expression, ${ }^{2}$ but are often used in Ogasawara to bless a reunion in the future.

\footnotetext{
1 The word itterasshai is not used for a long-term farewell in standard Japanese; it is usually used for sending off a person, who is soon returning, such as a child going to school.

2 It should be matane or mata oai shimasho in standard Japanese expressions. Rather than the verb miru (see), the verb au (meet) would be generally used in such a farewell occasion.
} 


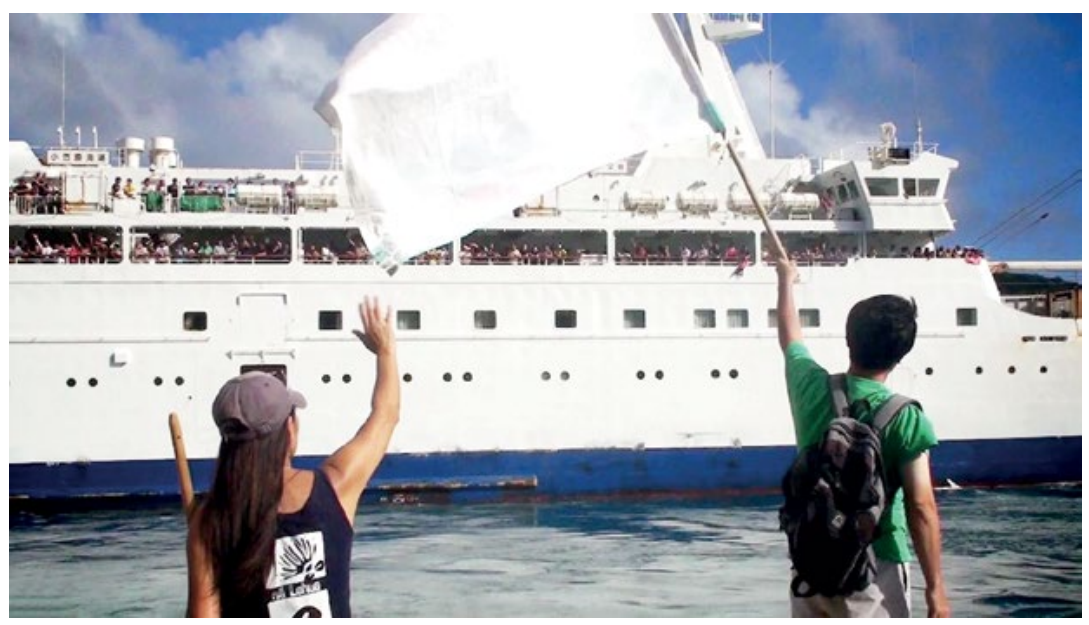

Figure 1. Sasaki Hitoshi and Minako waving a flag to send off the boat Ogasawara Maru

As the Ogasawara Maru slowly departs, the crowd waves their hands and approaches the edge of the pier to follow the boat. The passengers also wave their hands from the boat and, in participation of another island custom, throw leis previously presented by the islanders into the water. The leis float on the cobalt blue water symbolic of the passengers' hearts remaining on the islands. The sounds of taiko drumming can also be heard and continues echoing until the boat reaches the middle of Futami Bay. Several small local boats also follow the Ogasawara Maru beyond the bay towards the open sea as if to lament parting and separation. This farewell ritual of Ogasawara epitomises what Arnold van Gennep (1960 [1909]) describes in his rite of passage: préliminaire (separation), liminaire (transition), and postliminaire (reincorporation).

This chapter explores musical practices that help create bonding memories of the Ogasawara Islands, where life experiences are often transient. I present music and dance as vital media to construct collective and connective memories of people who are to be separated. As described below in detail, life in Ogasawara is full of ambiguity and difficulties often due to the small size and relative isolation of the island community. As a result, the Ogasawara population is constantly changing; many people leave Ogasawara after several years whilst many others migrate to the islands. Accompanying this passage of life, islanders employ music to describe Ogasawara's life, history, people, and their customs, and dance to embody the landscape, ocean, fauna, and flora of the islands. It is a communal process for remembering 
that unites people even after separation. The shared 'musical experiences' act as bodily practices for commemorative ceremonies and create strong bonds within the island community.

In the following sections, I briefly introduce the history and society of the Ogasawara Islands as a background. Colonial and post-colonial politics have resulted in various problems in this small region with nation-states having marginalised and neglected the island community in many ways. Reflecting this entangled history and society, Ogasawara musical culture displays complexity in its practices and performances. In this chapter, I defer from describing the details of this complexity (see Shishikura 2014 for such details), instead I focus on processes of memory construction that unite the community within a constant flux of people. The chapter describes transient life experiences that greatly influence the islanders' sentiments and reflect their musical activities multifariously. There are various songs expressing farewell sorrow and wishes for possible reunion in the future. Interestingly, these musical activities are often accompanied by bodily and dance practices. The corporeal experiences significantly increase performativities of the farewell ritual and enhance collective remembrances of the community. Through these arguments, I discuss how music and dance function in creating bonding memories despite a continuously changing island community in Ogasawara.

\section{The Ogasawara Islands}

The Ogasawara Islands are a cluster of small islands located in the Pacific Ocean to the south of Japan (Figure 2). These islands were virtually uninhabited until $1830^{3}$ when five European colonists and some 20 people from Hawai' $i$ first migrated to one of the islands, now called Chichi Jima. ${ }^{4}$ They settled on the islands with prospects of lucrative business with whalers and traders (Cholmondeley 1915: 17). Thereafter, more migrants arrived on the islands from Western countries and Micronesia, establishing a small autonomous community. However, in the 1870s, the Japanese Government began sending large waves of immigrants to colonise the islands as

3 There are some records of castaways who had arrived on these islands before 1830 (see Shishikura 2014: 132-46).

4 The five European colonists were Mateo Mozaro (Matthew Mazarro) of Dubrovnik, Croatia; Alden (Aldin) B. Chapin and Nathanael (Nathaniel) Savory of Boston, USA; Richard Millichamp (John Millinchamp) of Devon, England; and Carl Johnsen of Copenhagen, Denmark (Quin 1856). There is no specific record about the migrants from Hawai' $i$. 
Ogasawara of Japan. ${ }^{5}$ By default, European and Pacific Islander residents were forced to be shinmin, or obedient citizens, yet concurrently labelled as ijin (literally 'different people', but with connotations of 'aliens'). The Japanese administration continued for several decades, but was terminated with Japan's defeat in the Pacific War (1941-45). The United States then took control of Ogasawara and allowed only 'European descendants' to reside on the islands. 'Former Japanese settlers' were banished from their homes to become refugees on mainland Japan. Due to national security reasons, the navy segregated Ogasawara and severely restricted the islanders' activities with some neither leaving the islands nor communicating with their families and friends overseas. In 1968, Ogasawara was returned to Japanese administration. With the reversion, 'European descendants' were once again marginalised, and experienced difficulties and discrimination under the newly introduced social system. In 2008, Ogasawara village celebrated the 40th anniversary of reversion, yet some social problems caused by this complex history still remain unresolved (Arima 1990; Ishihara 2007; Shepardson 1977, 1998; Tanaka 1997).

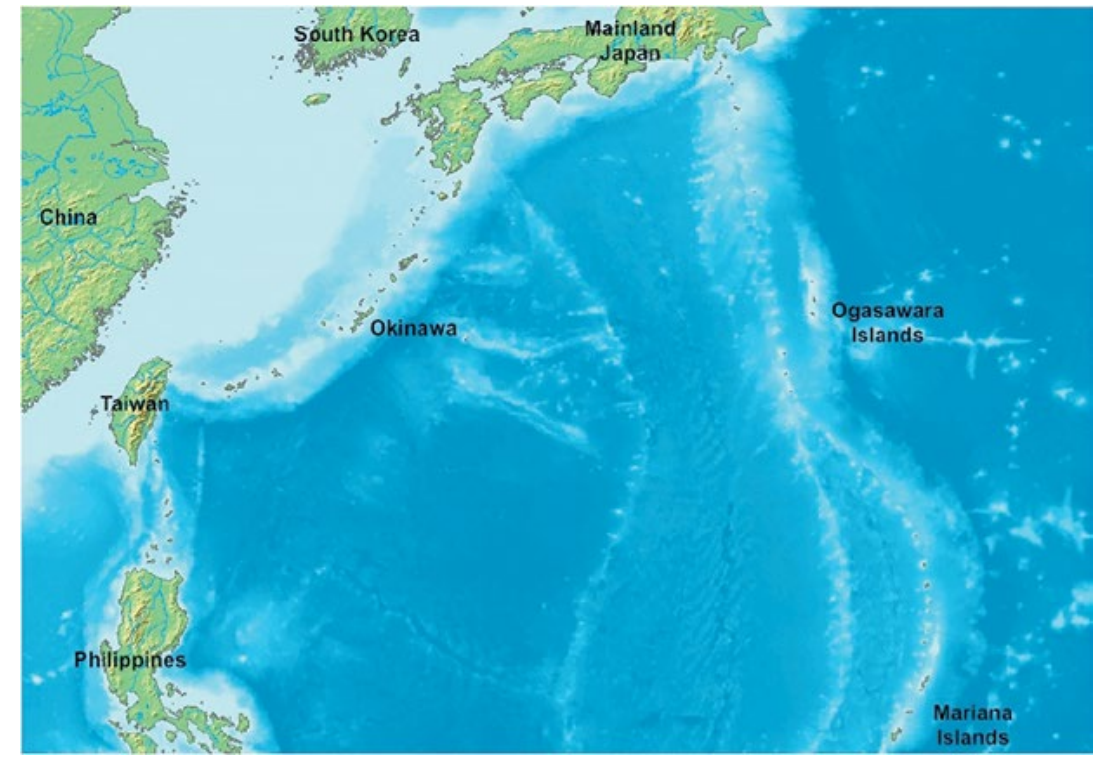

Figure 2. Map of the Ogasawara Islands

Source: Wikimedia Commons file (commons.wikimedia.org/wiki/File:Map_of_ogasawara_ islands.png), modified by the author

5 Prior to this, in the early 1860s, the Japanese Government had once sent immigrants to Ogasawara. However, they withdrew from the islands due to the Namamugi Incident (14 September 1862), and following international conflicts with the British Empire (Tanaka 1997: 182-208). 
Today, the Ogasawara Islands are essentially safe and at peace, although various social problems still cast shadows on island life. For instance, three types of residents are conventionally identified in Ogasawara, the minorities comprised of 'European descendants' (öbeikei tōmin) and 'former Japanese settlers' (kȳu tōmin), and the majority or 'newcomers' (shin tōmin), who moved to Ogasawara after the reversion. ${ }^{6}$ I acknowledge that these terms are problematic and include discriminatory overtones. It should also be noted that most of the 'European descendants' have Japanese lineage, as well as ancestors from the Pacific Islands, such as Hawai ' $i$ and Micronesia. ${ }^{7}$ Also, just like 'newcomers', many of the so-called 'former Japanese settlers' were born and raised on the mainland and then moved to Ogasawara after the reversion, although their families can trace their lineage back to pre-war Ogasawara. Some people use the term 'new newcomers' (shin shin tömin) in comparison to the 'newcomers', who migrated to the islands soon after the reversion (Kasuga 2002: 26-30), but there is no specific reference that differentiates the 'new newcomer' from the 'newcomer'. These discriminatory terms are ambiguous and uncertain; nevertheless they are still customarily used as labels between majority/ minority social groups in Ogasawara today. For some arguments, it might be useful to categorise Ogasawara people with the aforementioned labels. However, in the following arguments, I avoid using these discriminatory terms and concepts. Different people have arrived from different places, and they have strived to sustain the island life and community. They are all 'island people' who have contributed to the community, culture, and musical activities of the Ogasawara Islands.

Other social problems of Ogasawara include its small population and remoteness; these will be the focus of this chapter. Amongst the more than 30 tropical and subtropical islands of Ogasawara, only two are inhabited: Chichi Jima and Haha Jima. There are about 2,000 residents on Chichi Jima and less than 500 on the sparsely inhabited island of Haha Jima. The rest of the islands are currently uninhabited, although more than 1,000 people lived on the island of Iwo Tō (known as 'Iwo Jima' in English) before the Pacific War. Now, the island of Iwo Tō is exclusively utilised for military and other national interests, therefore public access

6 These terms are literally translated as 'European/American lineage islanders', 'former islanders', and 'new islanders', respectively.

7 Micronesia is one of the ancestral lands for the 'European descendants', since Maria Dilessanto migrated from Guam in 1843. She is recognised as 'the mother of Ogasawara', to whom almost all 'European descendants' are related (Long and Inaba 2004: 14). 
as well as civilian residences are prohibited. Since there is no airport, the Ogasawara Maru is the only public transportation to Ogasawara and takes 25.5 hours from the Tokyo metropolitan area. Travellers to Haha Jima have to take another two-hour trip by a small boat called the Haha Jima Maru. The Ogasawara Maru is available only once a week, ${ }^{8}$ so that the island community, given the global interconnectivity of today, is relatively isolated from the rest of the world (see Long 2002 for further discussion of the social conditions of Ogasawara).

\section{Musical memories of Ogasawara}

Reflecting its entangled history and society, Ogasawara musical culture reveals complexity in its practices and performances. Over generations, immigrants and travelling islanders from around the Pacific Ocean have contributed to the diversity of performing arts in this small and remote place. For instance, when Japan occupied Ogasawara in the late nineteenth century, the government recruited many migrants from neighbouring Hachijō Island, even though it is more than $700 \mathrm{~km}$ away from Chichi Jima. These migrants began practising Hachijō-style taiko drumming by embracing nostalgia for their place of origin (Wakazawa 2003); today, the islanders continue drumming the taiko at various occasions, such as shrine festivals and to send off the Ogasawara Maru.

When Japanese colonialism extended to Micronesia (1919-45), many Ogasawara Islanders travelled around the Pacific Ocean, seeking better job opportunities and quality of life. These travelling islanders eventually provided Micronesian dance that is now preserved as Ogasawara's cultural heritage of Nanyō odori (literally, 'South Pacific dance'). When the US Navy segregated Ogasawara after the Pacific War, the islanders sought affiliation with Micronesia, also controlled by the United States. Some of the islanders received temporary permission to work in Saipan or Guam, and encountered Micronesian songs written in Japanese lyrics. It is thought that Micronesians who received a Japanese education during the colonial period composed these songs (Kitaguni 2002: 129-60). These Micronesian songs are now recognised as Ogasawara koyo (classics), and are also preserved as part of Ogasawara's cultural heritage.

8 To be precise, the boat is available every six days, and it becomes available every three days during the high season for tourism. 
During the US Navy period, the islanders also enjoyed playing rock 'n' roll and country music. These musical activities continued after the reversion and developed into the islands' Music Lovers' Association. Nowadays, the association enriches Ogasawara musical events with various performances of rock, folk, punk, reggae, and instrumental music. Since the reversion and with globalisation, the islanders also expanded their musical activities and began practising choral singing, brass band, steel orchestra, and hula. Interestingly, these aforementioned musical activities are almost always localised and accommodated in Ogasawara. For instance, while showing respect to Hawaiian hula practices, the islanders often prefer to hula to local songs telling about Ogasawara. Nowadays, the Ogasawara Islands are filled with these various musical and dance activities that represent the plurality of Ogasawara musical memories (see Shishikura 2014 for further details of Ogasawara musical culture).

As described above, Ogasawara musical culture shows multiple interwoven layers of history, migration, and localisation that various scholars examine and interpret differently. For instance, ethnomusicologist Junko Konishi, often describes Ogasawara musical culture in association with Micronesia (such as 2001, 2002, 2003, 2004, 2005, 2008, and 2012). Her studies significantly increase our awareness of the small island community with extensive musical affinity beyond geopolitical boundaries. On the other hand, ethnomusicologist Henry Johnson (2004) examines Ogasawara songs that are featured in commercial recordings of mainland Japan, and argues that being 'domestic or exotic others' forms a significant part of Ogasawara's identity. It would also be possible to make arguments utilising such discourses as invention of tradition, cultural abuse of others, tourism, and globalisation. However, after extensive fieldwork experiences from 2008 to 2011, I have decided to evaluate Ogasawara musical culture with an emphasis on musical memories. I am interested in how musical activities create shared experiences and memories that connect people beyond distance. ${ }^{9}$ In this chapter, I am particularly concerned with contemporary life experiences of Ogasawara within a constant flux of people. To console the sorrow of farewell, the people of Ogasawara utilise music and dance, creating shared experiences and memories that unite

9 Although, in this chapter, I focus on the issue of bonding memories that appear in the transient life experiences of Ogasawara, the island musical culture also creates bonds with people in other ways. For instance, the diversity of musical genres affirms historical and cultural connections of Ogasawara beyond geopolitical boundaries. See Shishikura 2014, 2015a, and 2015b for further arguments concerning this. 
them even after separation. Below, I introduce discourses concerning collective memories and bodily practices that provide fundamental theories for the bonding memories of the Ogasawara Islands.

French sociologist Maurice Halbwachs (1992 [1925]) proposes the concept of collective memory that describes the shared memories in a group, community, and society. It explains how people acquire and share memories in society to construct collective identity. I like the term 'collective' as it suggests interactive and collaborative processes performed by people to create remembrance as a social phenomenon. I have identified various criticisms of the collective memory concept. For instance, Gedi and Elam make the argument that a community or society never retains 'a separate, distinct, single organism with a mind, or a will, or a memory of its own' (1996: 40-41). I agree that on a physical level an individual person remembers and retain memories. However, what I recognise as the collective memory is the processes of remembering that are often communal-dependant, collaborative, and constructive activities that unite human beings physically, as well as psychologically. Halbwachs's collective memory is still valuable in considering the processes of remembering that create a sense of belonging by sharing experience, memory, and locality.

Here, I utilise the word 'locality' that often takes a significant role in the construction of memories. French historian Pierre Nora (1996) focuses on the role of place and memories in his concepts, lieux de mémoire-sites, locations, or realms of memory. By utilising the word lieux, Nora suggests a collective approach to remember fragments of the past embedded in various places, sites, and locations, and tries to delineate the national topology of French memories. The lieux de mémoire signifies the place or locality for construction of collective memories, but the scope of lieux de mémoire needs to be extended beyond a nation and its boundary. In the book The Places of Memories of East Asia (Higashi Ajia no kioku no ba) (Itagaki, Jeong, and Iwasaki 2011), several scholars of Asian studies try to overcome the boundary recognised in Noras lieux de mémoire and search for shared memories of people living in different parts of East Asia. In considering the bonding memories of the Ogasawara Islands, the aforementioned arguments on lieux de mémoire are important on both sides. The life experience in the islands is essential in the construction of collective memories of Ogasawara, but more significantly, memories can be shared and connect people even after being separated by distance. In such a process of making lieux de mémoire of Ogasawara, music and dance play a significant role by providing bodily practices and performances. 
In his How Societies Remember (1989), sociologist Paul Connerton describes the process of social remembrance by referring to 'commemorative ceremonies' and 'bodily practices', and discusses commemorative ceremonies in association with rituals or rites of passage. I refer to the rites of passage in the beginning of this chapter, exemplified by the farewell practices of Ogasawara as they are indeed commemorative ceremonies for collective remembrance. Significantly, in his argument, Connerton states that commemorative ceremonies must be performative, that is, bodily practices are essential to conduct commemorative ceremonies. Here I extend his arguments and suggest that music and dance can be extraordinary performances for collective remembrance. In the Ogasawara Islands, people employ music and dance that function together as bodily practices for commemorative ceremonies. In the celebratory rituals of Ogasawara, music and dance practices produce physical and corporeal experiences that are inscribed into the body and remain as strong communal memories of the island people. In the following case study of Ogasawara, I describe commemorative ceremonies for farewell occasions, and argue that music and dance are exceptional bodily practices that produce powerful bonding memories.

\section{Transient island life}

As mentioned above, island life is often full of uncertainty, anxiety, and concern for the possibility of future departure. During my field trips, I have heard many conversations about hikiage (withdrawal) that can happen to anyone at any time. As a result, the islanders experience life in Ogasawara with a sense of nostalgia as it will be a place for sorrow and longing if hikiage happens. A local song, 'Island Life' (Shima gurashi), represents such a sentiment inscribed in an islander's heart.

Every morning, I take the way along the beach to my workplace

Riding a moped and humming

Ah, the Oga-maru [the boat Ogasawara Maru] is in the port

So, the island seems to be animated, I feel

For lunch today at Captain Cook

Will have a crêpe viewing the ocean

Ah, a sudden cloud from the mountains

With a squall, I am detained here for a while 
Such island life is ordinary

Yet it will certainly be nostalgic, if I return

The colour of sky gradually and gradually [changes]

This may become the best sunset

Ah, will hurry to the Weather Station ${ }^{10}$

Maybe she will be there too

Such island life, it is ordinary now

Yet if I return to Tokyo, certainly, certainly

Certainly, certainly, certainly, certainly

Certainly, I will feel nostalgic

(See original Japanese lyrics in appendix, translation my own)

I have never seen this crêpe shop, named after Captain Cook. ${ }^{11}$ It was located in front of the waiting room of the boat Haha Jima Maru, but closed down after only a few years of business. An informant told me that the couple who owned the shop left the island due to the wife's serious illness (anon., email, 2010). The composer of the song, Inoue Naoshi, ${ }^{12}$ still lives in Chichi Jima. He performs music on stage at a local music bar and at informal gatherings with friends (Figure 3). As a government worker, his island life is relatively stable compared to many others, but Naoshi still considers himself as withdrawn, having witnessed the departure of fellow islanders for many years. In the lyrics of 'Island Life', Naoshi longs for 'such island life' while recognising its impermanence.

10 Located on a hill called Mukazukiyama (Crescent Mountain), on Chichi Jima. It is a favourite local spot for sunset viewing.

11 Captain James Cook (1728-1779) never visited Ogasawara. After Cook's death, the HMS Resolution sailed around Iwo Tō in Ogasawara. His name is rather symbolic of voyaging in the Pacific, and can be extended to such stereotyped images of a south sea island as tropical, remote, savage, wild, and a sort of blank slate. Possibly the shop owners borrowed the label of 'Captain Cook' by embracing nostalgia for the Pacific, which is a place to be explored, but not a promised land-even if one hopes so. It seems that the Ogasawara Islanders still preserve such a sense of expedition and consequent withdrawal at the end.

12 The order in Japanese names here is family name first and then given name, as in normal Japanese usage. In adherence to islands' custom, I call the Ogasawara Islanders by their first names, even though this is rather unusual on mainland Japan. 


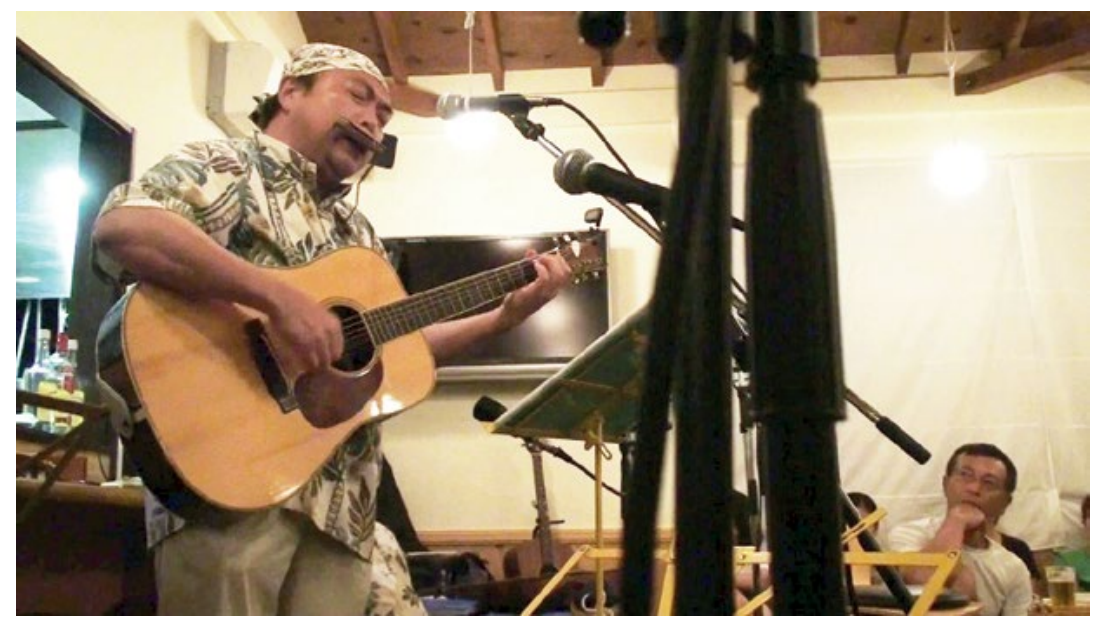

Figure 3. Islander Inoue Naoshi singing 'Island Life'

Census data indicates that 18.8 per cent of residents left Ogasawara in 2001; the number is more than three times the national average of 4.8 per cent (Ministry of Land, Infrastructure, Transport, and Tourism 2003: 3). If evenly distributed across the population, it would mean that the entire population of Ogasawara changed every six years or so. In fact, almost every adult islander has experienced life in another place for several years. This implies that he or she must have experienced either a departure from or migration to the islands at least once. In particular, people who move to Ogasawara for employment tend to leave the islands sooner, ${ }^{13}$ yet hikiage is a shared concern amongst the residents who accept that life in Ogasawara is uncertain and unstable.

There are various reasons for withdrawal, including scarcity of job opportunities. The main industry in Ogasawara is tourism, and it cannot provide sufficient employment for residents due to the limited numbers of visitors to the islands. In off-peak season, there are less than 400 passengers in each trip of the liner boat. It is possible to be a fisherman or farmer in Ogasawara, but such work is not always lucrative, with income from these occupations providing only 1.1 per cent and 0.4 per cent, respectively, of the total income of the islands. ${ }^{14}$ Owning a restaurant or bar is also

13 Such as schoolteachers and workers of the Tokyo prefectural government.

14 The Ogasawara Fishermen's Union provides generous support for its members, and there are successful fishermen, as I have recognised. However, their lives are still uncertain and risky, often with much debt resulting from the purchase of a fishing boat. 
difficult in a place with only 2,500 people, subsequently these businesses depend upon tourism as well. As a result, many residents have temporary employment and eventually leave the islands after several years.

In addition, many of the current residents are not from Ogasawara and have no family lineage, or own real estate, on the islands. This means that they must take the 25.5 -hour voyage, available only once a week, if there is a family problem on the mainland. The scarcity and high price of real estate makes it almost impossible for islanders to purchase land and a house. According to statistics, only 16.8 per cent of residents have their own houses, with other residents renting apartments or other types of housing (Ministry of Land, Infrastructure, Transport, and Tourism 2003: 3). Even if they cope with low income and being away from their families, residents still have to think about the possibility of hikiage for other reasons, such as health problems. There is only a basic clinic on each of the Chichi Jima and Haha Jima Islands; I have noticed many elderly islanders travelling on the boat for hospital and medical care with the possibility they will not return home if intensive care is required. Hikiage is an everyday word amongst the islanders and can happen to anyone unexpectedly.

It seems that impending separation between friends and family is part of the ordinary life cycle in Ogasawara. Departure and absences are usual, daily experiences and weigh heavily on the islanders' hearts. People leaving the islands often abandon many of their belongings because it is cheaper to buy brand-new goods than ship used items from this remote place. Ayumi's Shop is a recycling station in the Welfare Centre that accepts donated items for reuse. Large piles of second-hand goods, such as clothes, furniture, tableware, and toys, remain at the corner of the building as if to represent an accumulated sorrow from transient life. Locals often take it for granted by saying: 'Many people leave, many others come instead, and some useful goods remain here for us'. However, such a constant flow of people clearly impacts island life by appearing in the musical activities of Ogasawara.

\section{Songs for distance}

The sentiment of hikiage, departure, and separation, permeate Ogasawara musical culture in many ways. During my fieldwork, I encountered various songs for departure and farewell occasions. The 'Song of Farewell' (Sōbetsu no uta) is one such example that an island singer, 
Edith Washington, sang at a farewell party of the Nanyo odori group. At the party, Edith stated: 'I've heard that many people leave the islands at this time. I thank you all who are departing, for your contributions to the islands. To express my gratitude, I would like to send you with this song of farewell' (March 2010, Figure 4).

Our friendship has lasted years, my dear friend

Today we separate, my heart is sad

Ah dear, dear my friend, farewell

Farewell, dear my friend, take care indeed

Live with sincerity, do our duty in a society

We wait, farewell, for the day we will enjoy together again

Farewell dear friend, dear my friend, farewell

Farewell my friend, take care indeed

(See original Japanese lyrics in appendix, translation my own)

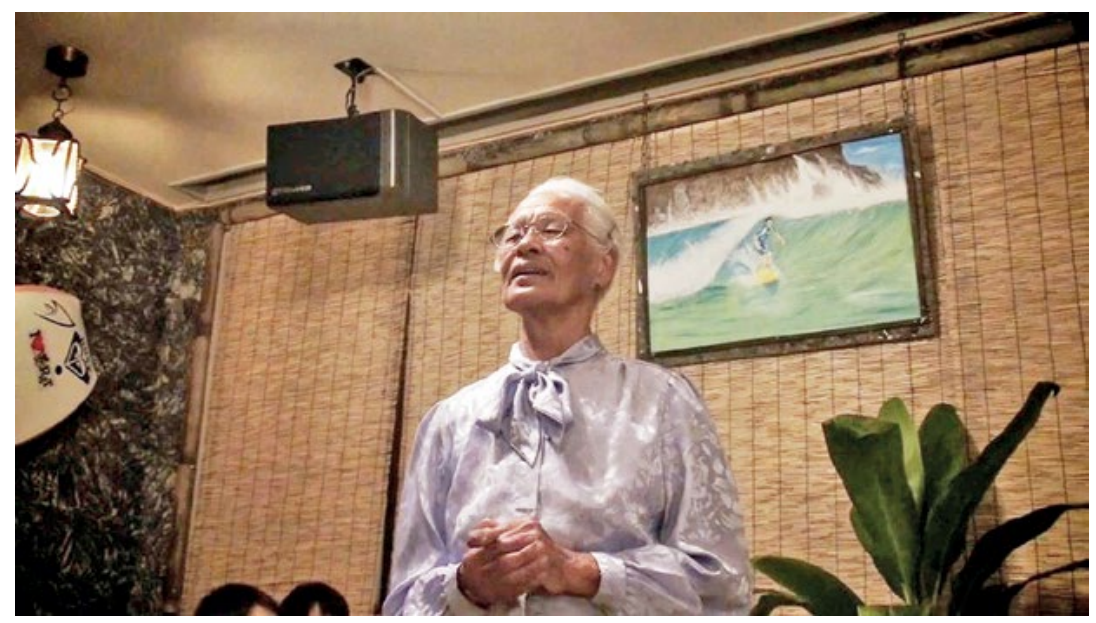

Figure 4. Edith singing 'Song of Farewell'

Edith has lived in Ogasawara since the pre-war period, experiencing forced evacuation during war time, and suffering segregation under the US Navy. She has also played a significant role in reviving Ogasawara musical culture since the reversion. In her long life on Ogasawara, Edith enjoyed music and dance with many visitors and friends that she would eventually say farewell to. During interviews with me (2009-10), Edith spoke about various memories of her friends - most of them humorous and exciting, yet some a little sad as well. She remembers the days they sang and danced together, and now within the song, Edith embraces her 
affinity with departing fellow islanders. The 'Song of Farewell' epitomises sentiments of separation that imperatively occur in the complex lives of transient islanders and act as a memory device connecting Edith with her old friends, even after being apart.

I consider Edith Washington to be an exceptional woman, who has experienced island life for a very long time, probably more than anyone else. The sentiment of farewell, however, is rather a shared or collective emotion that appears amongst many islanders, including those who moved to Ogasawara in relatively recent years. The song 'Precious Thing' (Taisetsuna mono) is one such composition written by a recent migrant that exemplifies the widely shared sentiment of separation in the island community.

On the day when the colour of the ocean becomes the same as the sky

Let's go out, bringing the 'ukulele, sitting on the beach filled with coral sand

Sing a song towards the sky

When we get together, smiles come out

On this favourite island, dance hula together again

On the day when the colour of sky becomes the same as the ocean Let's get to the other side of the island, towards that windy hill Let's go, driving a car fast

With many joys, smiles come out

On this favourite island, dance hula together feeling the winds

On the day when the colour of the bide flower becomes the same as the sunset

Let's climb that big tree, at the place near the stars

Let's sing the song of stars together

Although many farewells result in tears

On favourite Chichi Jima, I wish to dance hula together again

Our hearts continue to be connected beyond distance

The sky we watched together, that is my precious thing forever

(See original Japanese lyrics in appendix, translation my own)

The song first describes daily experiences of the islands, such as 'sitting on the coral sand beach', 'driving a car towards the windy hill', and 'climbing that big tree to come close to the stars'. But, towards the end, it suddenly turns into a song of farewell, as if to depict the sudden feeling of withdrawal and abandonment that often occurs in Ogasawara. 
As suggested in the lyrics, the composer left the islands several years ago, but the song still retains popularity in Ogasawara, especially in association with hula activities. It was choreographed for hula and is often performed at farewell occasions. The hula represents and embodies islanders' hearts; the memories of island days connect people separated by distance possibly uniting them 'to dance hula together again' in beloved Ogasawara (Figure 5).

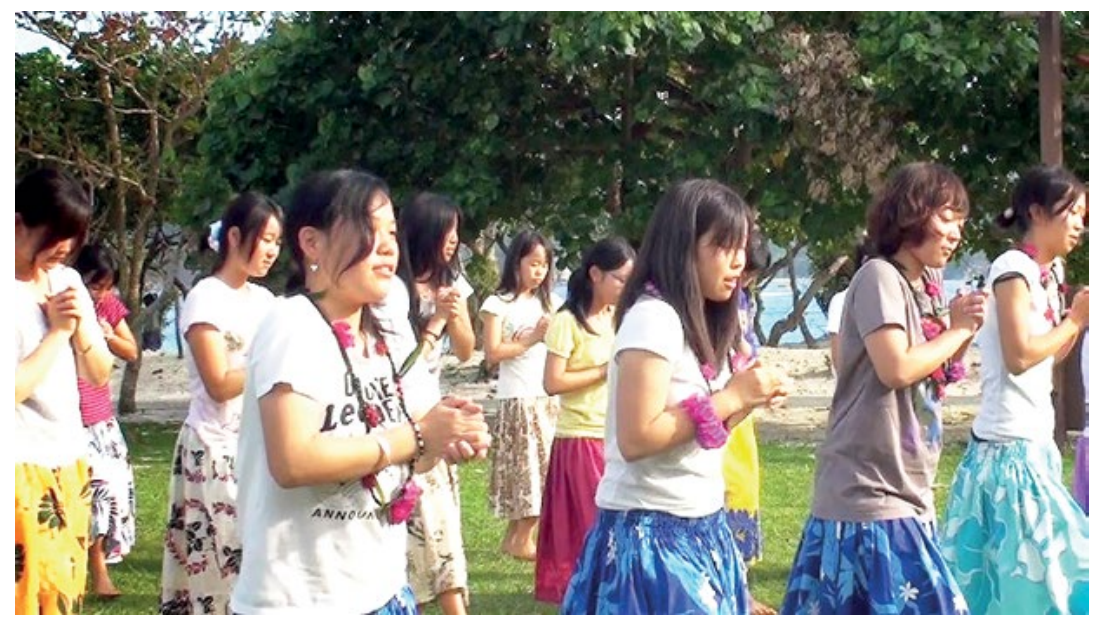

Figure 5. Student performance of hula 'Precious Thing'

As exemplified above, the sentiment of farewell is a collective feeling shared by those who remain on the islands and those who leave. Yet, the farewell sentiment often spills over when the community deals with sending their own children off the island. Ogasawara is sometimes called a 'paradise of children' (e.g. see Takayama 1986: 148-51) with its landscape ideal for children to play in and a community attentive to the children. ${ }^{15}$ However, this paradise is temporary and transient. Many children leave the islands when their parents relocate for work purposes. Children who do remain are still expected to leave home for higher education or job training, fulfilling a rite of passage to be an adult member. Once they have left the islands, there is no guarantee of return as there are few employment opportunities. Ogasawara is a transient place for children as well as adults.

15 Also, there is a song entitled 'Our Paradise' (Bokura no paradaisu) that was composed for a farewell performance of high school students in 2010 (see below for farewell rituals of high school graduates). 
The community sends the children with best wishes for their productive life away from home and hopes for a possible return after having significant experiences. The song 'Journey of Green Sea Turtle' (Aoumigame no tabi) expresses such a complex sentiment of the islanders who send their children away with anxiety and blessing for their possible return someday in the future:

From the beach of the island in summer, dashing towards the ocean

It is the beginning of the journey of baby sea turtles

Live, live and survive, each one, every child, when full grown

Come back to this beach someday

(excerpts, see full Japanese text in appendix, translation my own)

Subsequent verses describe the baby sea turtles 'facing the storm, chased by a shark, and targeted from the sky by a seabird'. ${ }^{16}$ The islanders acknowledge the children's hardships after leaving the paradise. They may not return, but the adults hope that the children will at least remember the islands through memories of songs and dances they have enjoyed together. The song was also choreographed for hula and has become the finale ritual performance to close the island annual hula festival (Figure 6).

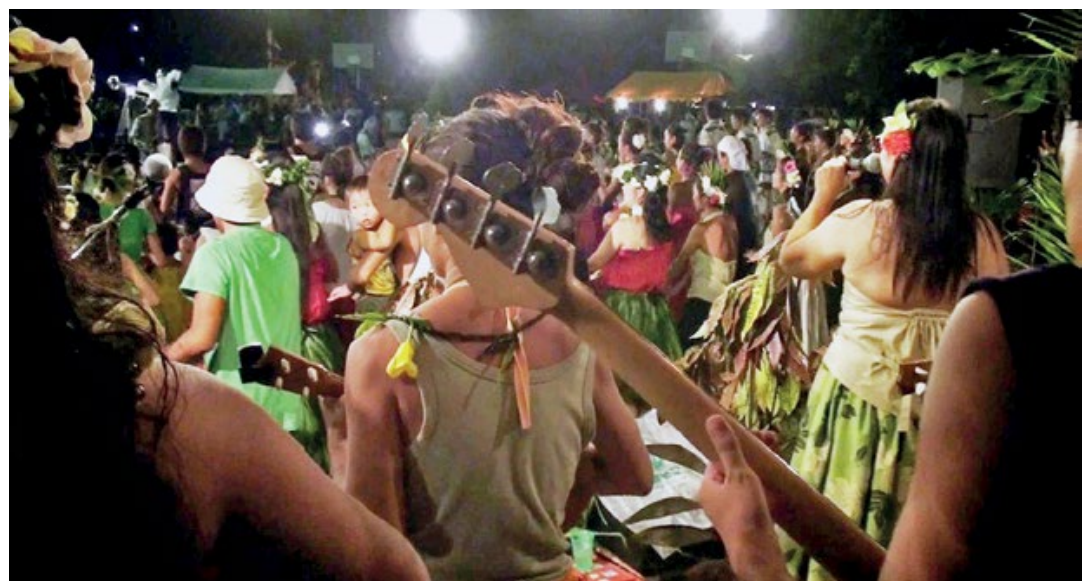

Figure 6. Performance of 'Journey of Green Sea Turtle' at the Ogasawara hula festival

16 The lyrics say: 'Facing the storm, chased by a shark, and targeted from the sky by a seabird, towards the north, painful road, dawn and sunset, and again morning, each day, every day, growing up, and again, the journey towards home continues. Youthfulness shines on the ocean and sky, laying hundreds of eggs, covering them with sand and prayers, live, live and survive, each one, every child, when full grown, come back to this beach someday.' 


\section{Dancing to be connected}

As exemplified in the songs 'Precious Thing' and 'Journey of Green Sea Turtle', the islanders often mix singing and dancing activities trying to enrich their musical experiences through dance practices. Their conflated musical/dancing bodies increase the sense of unity strongly acting as a memory device for collective remembrance. Here, I return to Connerton, and his concepts of 'commemorative ceremonies' and 'bodily practices'. He states: 'Commemorative ceremonies prove to be commemorative only in so far as they are performative' (1989: 71). In the ritualistic process of remembering the islands, bodily practices take a significant role in the creation of bonding memories.

As proposed by Connerton, the Ogasawara Islanders utilise the body and its practices extensively in farewell occasions. The aforementioned practice for boat departure is a good example. Besides waving flags and chasing the liner, the islanders send people off through musical and corporeal (body) performances. For instance, the group of Nanyo odori often present their performance before the boat departure, stating: 'We send you with this dance of the island cultural heritage, a blessing for your safe voyage and our reunion here in Ogasawara'. Likewise, taiko drummers address the passengers by saying 'Hope you have enjoyed Ogasawara and will come back to the islands in the next year', before performing the taiko piece, 'Sperm Whale Drumming' (Makkō daiko), specially composed to send off the boat. At the port, the hula group often sends off their own members by dancing favourite numbers, such as the 'Precious Thing', together as if to affirm collective memories of the island dance. When they are not performing during boat departure, the islanders often utilise music and dance for farewell gatherings and parties strengthening bonds prior to departure. A gathering called oidashi hula ('kicking-out' hula) is a good example that is held annually in March to celebrate the departure of high school graduates. ${ }^{17}$ Music and dancing constitute the ritual for farewell that creates collective and connective memories after being separated.

Here again, the occasions of sending off island children typically exemplify the bodily practices that facilitate a farewell ritual. Through hula dancing, people try to remember the days they spent together on their beloved Ogasawara. As prominent Hawaiian kumu hula (hula master/teacher)

17 March is the month for graduations in Japan. 
Ma'iki Aiu Lake suggests, hula has the potential to incorporate and embody history, culture, society, and living space through dancing bodies (cited in Ariyoshi 1998). Ogasawara hula activities are not an exception, often describing landscape, ocean, fauna, flora, and people of the islands. The narratives inscribed in song lyrics are embodied by dancing and remain as corporeal experiences of the Ogasawara Islands. In the following sections, I shall describe farewell hula performances for departing high school students.

The first time I observed a farewell hula performance was in late April 2009, when a local songwriter, Tamura Midori, showed me a draft of a new composition that was to be choreographed for hula and performed by high school seniors at the island hula festival held in August. The song lyrics were filled with affection and gratitude for their island home:

An orange road appears on the sunset ocean

The brilliant road leading us to our dream far away

Feeling the island summer day on my back

Embraced by the starry sky, I close my eyes

Cheerleading, Bỉde cultural festival: ${ }^{18}$ each event I remember

There, numerous smiles are overflowing

It is just like a relay race

We send a baton received from past graduates to juniors with best wishes, and fly to leave

Even if there appears a wall that blocks the road to the future

We will surely overcome it with the power granted from you all

Sails of windsurfing embellish the ocean,

Flowing clouds and winds are bringing the summer

The ordinary days, we spent together, are now far away, I feel

Sorrow remains in my heart

We sent past graduates riding on a boat and holding cheering flags

Now we will be sent off, wipe tears out and let's move on

Farewell the scenery I am familiar with, farewell the colour of ocean

I see everyday

Farewell you all just in front of us, it will be for a while, so farewell

18 Annual school events of Ogasawara High School. 
Thank you, we are here now, thank you for rearing us

Till yesterday and from now on too, thank you for your

overwhelming love

Thank you for the overwhelming love

(see original Japanese lyrics in appendix, translation my own)

The composer of the song Tamura Midori, leaving the song untitled, explained to the students: 'It is everything about the islands-nature, history, community - that reared you all'. After hearing the explanation, the students decided to entitle the song 'In the Wind of Mana' (Mana no kaze no nakade). Mana means 'supernatural or divine power' in Hawaiian, and was also a nickname of Yamaguchi Manami, the island hula teacher. Just like Lake advises, Manami has taught her students that hula speaks about landscape, people, and their customs, and must portray the islands of Ogasawara through bodily movements. In the song lyrics, the students found the 'mana of Ogasawara' that has reared them until today, and through dance they embodied the mana. In the festival, they performed the hula with sincere gratitude to the islands, which were inscribed as their bodily memories (Figure 7).

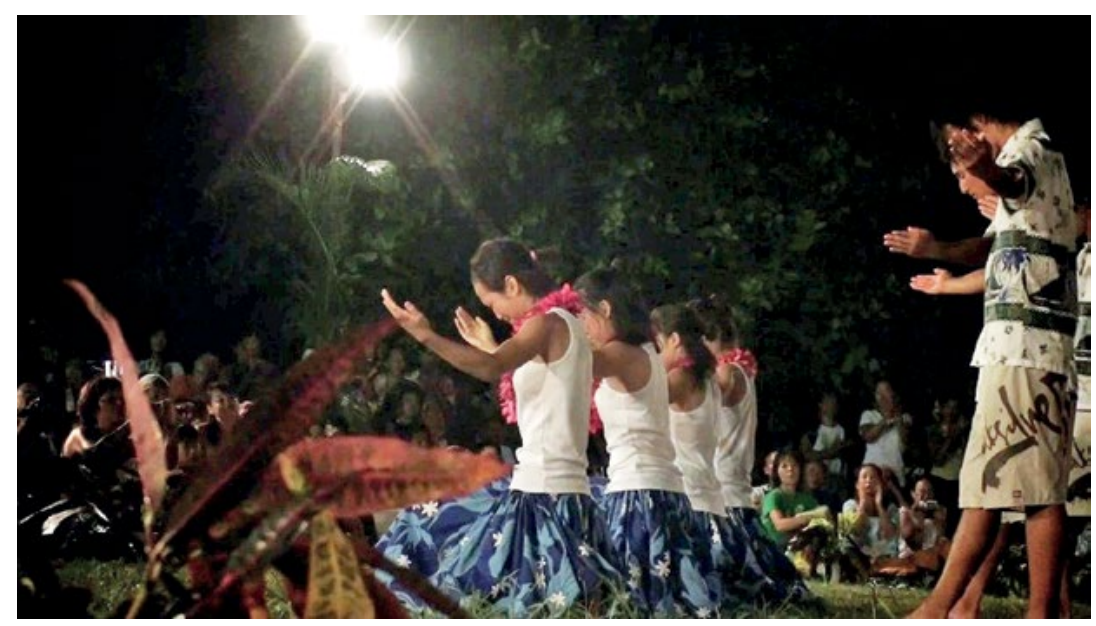

Figure 7. The finale of hula 'In the Wind of Mana'

There are high school graduates every year, so that the island community conducts ritual practices for departing children annually. Since 2009, Tamura Midori and Yamaguchi Manami have collaborated to produce a newly composed farewell hula for high school seniors each year. In 2011, 
they created the hula entitled 'The Bond' (Kizuna). Again this hula song describes the daily life of high school students, yet the lyrics also describe 'the strong bond that connects you and me'.

The long way up to the hill, I have commuted (to the high school) until today

From tomorrow, I'll walk up to another hill

The everyday view of Futami Bay (of Chichi Jima) from the classroom

I like the sparkles of waves that I see today as yesterday

I hear the practice voices of the boys' cheer team from the rooftop

I am sewing their headbands with encouragement

Harsh words hurt with each other

In the difficult days, you embraced my shoulders

And talked together overnight

If everything falls in dark, it can't be changed

The strong bond that connects you and me

The great Milky Way casting over the night sky of July

Yesterday, today, and tomorrow, it flows continuously

The small cherry tree by the school building

What kinds of smiles, she welcomes this year

From here, to the world, and to the future

(original lyrics in Japanese, translation my own)

Besides the farewell ritual practices for high school graduates, it seems to me that the song epitomises the transient life experiences that appear in the history of Ogasawara. Since the first settlement, the islands have experienced numerous flows of peoples through exploration, colonisation, forced evacuation, and reversion. As suggested by the lyrics, the island community still endures various problems caused by the entangled history of exploration, colonisation, forced evacuation, reversion, and related conflicts amongst the 'categorised' islanders. However, I have often noticed that the community adapted and united themselves through music and dance activities. The song lyrics describe alienations that have appeared in Ogasawara, as well as the everlasting bond 'between you and me' through such metaphoric expressions as 'continuously casting Milky Way' and 'the cherry tree welcoming new faces every year'. The students' dancing bodies represent the resolution of the sorrow that permeates in their life experiences and incarnates the strong bonds that transcend the difficulties and alienation of the islands. Through dance practices, 
collective memories of Ogasawara are inscribed in the bodies of island children, and will connect people beyond distance 'from here, to the world, and to the future' (Figure 8).

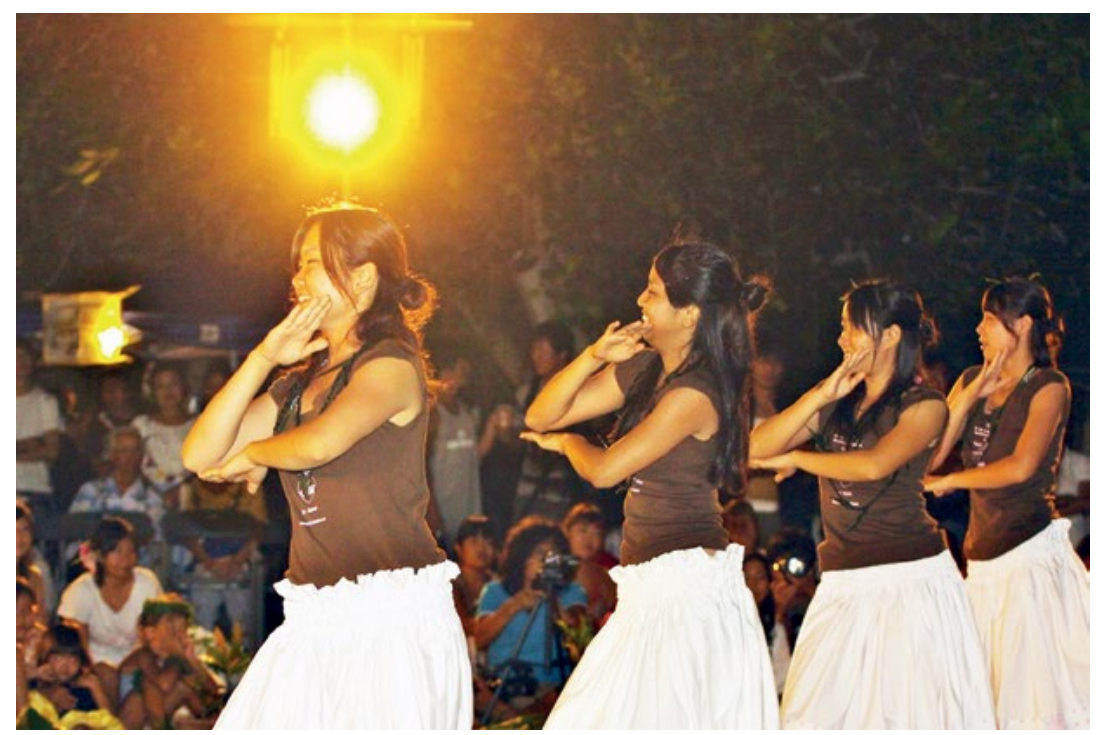

Figure 8. Hula 'The Bond'

Source: Courtesy of Tomita Masuo

\section{Conclusion}

Just like the tides of the ocean, people constantly come and go from the Ogasawara Islands. In his song 'Island Life', Inoue Naoshi recognises that farewell is imperative for members in this small island community. 'Island Life' certainly expresses islanders' hearts just as Edith Washington embraces memories of fellow islanders within the 'Song of Farewell'. The song 'Precious Thing' describes how the islanders sing and dance together, creating precious collective memories of Ogasawara. Music and dance are vital media to conduct 'commemorative ceremonies', because their performativities facilitate the ritual practices of farewell towards collective remembrance. Through musical and dancing bodies, the islanders preserve shared experiences, memories, and sentiments, and construct collective memories of this remote, yet extensively connected place. 
Throughout its history, the Ogasawara Islands have suffered colonialism, war, forced evacuation, segregation, and reversion to Japanese administration. The island community has often been marginalised and placed in a subordinate position to Japan. The sorrows of the islands are a result of larger national and international politics that impact on Ogasawara musical activities in multiple ways. However, the islanders never preoccupy themselves by lamenting misfortune and try to resolve their sorrow through collective remembrances. As exemplified in the song 'Journey of Green Sea Turtle', the farewell ritual for island children typically represents the islanders' sentiment for a sustainable future. The children remember Ogasawara in their musical and dancing bodies that connect them with the islands long after their departure. The song 'In the Wind of Mana' is inscribed into the bodies of island children, and acts as memory device to remember Ogasawara. In such a collective process of remembrance, the Ogasawara people preserve and sustain the unity of the community beyond parting and separation. Together with the island children, 'The Bond' of Ogasawara will be perpetuated into the future. Memories connect people despite distance; music and dance greatly helps to create bonding memories_-songs for distance, dancing to be connected.

\section{Dedication}

This chapter is from my $\mathrm{PhD}$ research supervised by Stephen Wild. Amongst our mutual and collaborative communications, I particularly remember when Stephen first read my description of 'departing high school students' in the advisory meeting, thereby prompting Stephen to share his own story. In the late 1960s, a boat trip was common for travel overseas. Stephen took a boat and departed from Perth, Australia, to pursue his $\mathrm{PhD}$ studies at Bloomington, Indiana, in the United States. Leaving his family for the first time, he was filled with expectations and excitement for his prospective life in the US. But from the departing boat, Stephen saw his mother crying at the pier. He did not understand why his mother was crying, but later he supposed that his mother realised her beloved son would not return home and live with her anymore. As his mother anticipated, Stephen achieved a productive academic life in other places, and never returned. I left Stephen in 2013, and have had no chance to visit Australia since then. But memories of our days in Canberra remain connecting Stephen and me beyond distance. This is for you, Stephen. 


\section{Acknowledgements}

Many thanks to Made Mantle Hood for his friendship and generous support of my academic writing.

\section{Appendix: Japanese song lyrics}

\section{'Island Life' (Shima gurashi)}

島暮らし

毎朝、海沿いの道を職場まで

原チャリ飛ばして鼻歌まじりで

ああ、おが丸が港にいるから

何となく島中がにぎやかな感じ

今日のお昼はキャプテンクックで

海を見ながらクレープでも食べよう

ああ、急に山からの雲で

スコールに少しここで足止め

こんな島暮らし普通だけれど

帰つたらきつと懐かしいんだろな

空の色が少しずつ、少しずつ

どうやら最高の夕焼けみたい

ああ、急いでウェザーまで行こう

もしかしてあの娘も来ているかもね

こんな島暮らし今は普通だけど

東京に帰つたらきつと、きつと

きっと、きつと、きつと、きつと

きっと懁かしく思えるんだろな

(transcribed from my own recording, 17 October 2009) 


\section{‘Song of Farewell’ (Sōbetsu no uta)}

送別の唄

年頃むつびし いとしい我が友よ

今日ぞ別れ行く わが胸ふさがりぬ

ああ わが友 サラバ わが友

サラバ わが友 いよよ すこやかに

人の道をまもり 世のつとめはたし

われらまたん サラバ 又こん楽しき日

サラバ わが友 サラバ わが友

サラバ わが友 いよよ すこやかに

(transcribed from a manuscript gifted to the author, January 2010)

\section{'Precious Thing' (Taisetsuna mono)}

大切なもの

海の色が空と同じになる日

ウクレレもって出かけよう

サンゴダストのビーチに座り

空に向かって歌おう

みんなが集まれば 笑顔になれる

大好きなこの島で またみんなでフラを踊ろう

空の色が海と同じになる日

島の向こうへ出かけよう

風の吹くあの丘に向かって

車飛ばして出かけよう

うれしいを集めれば 笑顔になれる

大好きなこの島で

風を感じてフラを踊ろう 
ビーデの色が夕日と同じになる日

あの大きな木に登ろう

星に近い場所へ登ったら

みんなで歌おう星の歌

さよならを集めたら 涙になるけど

大好きな父島で

またみんなでフラを踊りたい

どんなに離れてても思いは繋がってゆく

一緒に見たあの空は

ずっと私の大切なもの

(transcribed from my own recording, 29 August 2009)

'Journey of Green Sea Turtle’ (Aoumi-game no tabi)

アオウミガメの旅

真夏の島の 浜辺から

海に向かって まっしぐら

子ガメの旅が 始まった

生きて 生きて 生き女いて

ぞの子も どの子も 大きくなって

またこの浜に 帰つておいでよ

あらしに出会い サメに追われ

空からねらう 海鳥たち

北へ北への つらい道

明けて 暮れて また朝に

来る日も 来る日も 大きくなって

またふるさとへ 旅は続くよ

若さがかがやく 海と空

百個の白い たまご生み

いのりをこめて 砂かける

生きて 生きて 生き女いて

ぞの子も どの子も 大きくなって

またこの浜に 帰つておいでよ

(Ohama and Machida 1991: 30) 


\section{'In the Wind of Mana' (Mana no kaze no nakade)}

マナの風の中で

夕暮れの海に オレンジの道ができる はるかな夢に続く あざやかなこの道 島の夏の日を 背中で感じながら 夜空の星の中で ただ目を閉じる

チアーリーディング ビーデ祭 思い出の一つ一つ 数えきれない笑顔たちが ほらあふれている

先輩から受け取った リレーのバトンのように 後輩に思いをたくして 私たちは羽ばたく 時には目の前に壁が 未来の道をふさぐけど みんなからもらったこの力で きっと乗り越える

ウィンドサーフィンの セールが海を飾る 流れる雲も風も 夏をはこんでくる 当たり前のように 過ごしてきた毎日が 遠くに感じられて なんだかさびしい

先輩たちの見送りに 団旗を持って走った海 今度は僕ら見送られる番さ 涙をふいて進もう さよなら 見慣れた景色 さよなら いつもの海の色 さよなら 今目の前の君 少しの間 さよなら

ありがとう 今ある僕を(私たちを)

育ててくれて ありがとう(ありがとう)

昨日までも そしてこれからも 大きな愛を ありがとう 大きな愛を ありがとう

(transcribed from my own recording, 29 August 2009) 


\section{'The Bond' (Kizuna)}

絆

今日まで通い続けたこの長い坂道も

明日からは違う坂道 登って行くんだろう

教室の空から見えるいつもの二見湾の

波間のきらめきが好きで 今日も眺めている

屋上から響き渡る 男子の援団の声

頑張れの想い布に込め 針を進女ている

尖つた言葉で傷つけた

辛い日は肩を抱き合った 共に悩み打ち明けて

語り明かした夜

全てが闇に包まれても 変わらないものがある

あなたと私を結ぶ 強い絆が

7月の空を彩る 大きな天の川は

昨日も今日もまた明日も 空を流れて行く

校舎のそばに寄り添う あの小さな桜の木

今年はまたどんな笑顔 迎えて行くんだろう

ここへ 世界へ 未来へ

(Tamura Midori, email, September 2015)

\section{Glossary: Japanese words in the text}

$A u$ 会う

Bokura no Paradaisu 僕らのパラダイス

Chichi Jima 父島

Hachijō 八丈

Haha Jima Maru 母島丸

Haha Jima 母島

Hikiage引き揚げ

Ijin 異人 
Itterasshaiいつてらつしゃい

Iwo Tō 硫黄島

Koyō古謡

Kyū tōmin 旧島民

Makkō Daiko マッコウ太鼓

Mata miruyo またみるよ

Mata oai shimashō またお会いしましょう

Mataneまたね

Miru 見る

Mukazukiyama 三日月山

Nanyō odori 南洋踊り

Newcomers 新島民

Ōbeikei tōmin 欧米系島民

Ogasawara Maru おがさわら丸

Ogasawara 小笠原

Oidashi 追出し

Sayonaraさよなら

Shin shin tōmin 新新島民

Shin tōmin_新島民

Shinmin 臣民

Taiko 太鼓

\section{References cited}

Arima, Midori. 1990. 'An Ethnographic and Historical Study of Ogasawara/the Bonin Islands, Japan.' PhD diss., Stanford University.

Ariyoshi, Rita. 1998. Hula Is Life: The Story of Hälau Hula O Maiki. Honolulu: Maiki Aiu Building Corporation, Inc.

Cholmondeley, Lionel Berners. 1915. The History of the Bonin Islands. London: Constable.

Connerton, Paul. 1989. How Societies Remember. Cambridge: Cambridge University Press. doi.org/10.1017/CBO9780511628061. 
Gedi, Noa and Yigal Elam. 1996. 'Collective Memory-What Is It?' History and Memory 8 (1): 30-50.

Gennep, Arnold van. 1960 [1909]. The Rite of Passage. Translated by Manika B. Vizedom and Gabrielle L. Caffee. London: Routledge.

Halbwachs, Maurice. 1992 [1925]. On Collective Memory. Edited and translated by Lewis A. Coser. Chicago: University of Chicago Press.

Ishihara Shun 石原俊. 2007. Kindai Nihon to Ogasawara Shotō: Idō-min no shima-jima to teikoku 近代日本と小笠原諸島: 移動民の島々と 帝国 [The Japanese Empire and the Ogasawara/Bonin Islands: Sociohistorical studies on the naturalised people's encounters with sovereign powers]. Tokyo: Heibon Sha.

Itagaki Ryuta 板垣竜太, Jeong Ji Yong 鄭智泳, and Iwasaki Minoru 岩 崎稔編著. 2011. eds. Higashi Ajia no kioku no ba 東アジアの記憶 の場 [The places of memories of East Asia]. Tokyo: Kawade Shobō Shinsha.

Johnson, Henry. 2004. 'To and from an Island Periphery: Tradition, Travel and Transforming Identity in the Music of Ogasawara, Japan.' The World of Music 46 (2): 79-98.

Kasuga Sho 春日匠. 2002. 'Katararezaru rekishi no shima, Ogasawara no kizoku to jūmin' 語られざる歴史の島、小笠原の帰属と 住民 [The island of untold history, residents, and belonging of Ogasawara]. In Ogasawara gaku koto-hajime 小笠原学ことはじめ [The introduction of Ogasawara studies], edited by Daniel Long ダニ エル・ロング, 11-32. Kagoshima: Nanpō Shinsha.

Kitaguni Yu 北国ゆう. 2002. 'Ogasawara Shotō no minyō no juyō to henyō: Sono koto-hajime’ 小笠原諸島の民謡の受容と変容:そのこ とはじめ [Adaptation and change of the folksongs of the Ogasawara Islands: An introduction]. In Ogasawara gaku koto-hajime 小笠原学 ことはじめ [The introduction of Ogasawara Studies], edited by Daniel Long ダニエル・ロング, 129-60. Kagoshima: Nanpō Shinsha.

Konishi Junko 小西潤子. 2001. 'Developing Tradition: The Origin and History of Music in the Ogasawara Islands.' Perfect Beat 5(2): 30-48. 
2002. 'Uta ya geinō no ekkyō to aidentiti no sōzō: Ogasawara no minyō no arenji o megutte’ 歌や芸能の越境とアイデンティティの創 造:小笠原の民謡のアレンジをめぐつて [Songs and entertainments beyond borders and creation of identity: Concerning arrangements of Ogasawara folksongs]. In Ogasawara gaku koto-hajime 小笠原学こ とはじめ [The introduction of Ogasawara Studies], edited by Daniel Long ダニエル・ロング, 161-93. Kagoshima: Nanpō Shinsha.

—. 2003. 'Umi no rūto to junkan suru rūtsu: Uta to odori ni yoru Mikuroneshia tono kōryū’ 海のルートと循環するルーツ: 歌と踊り によるミクロネシアとの交流 [Marine routes and circulating roots: Exchanges of music and dance with Micronesia]. Kikanshi i-Bo 季刊 誌 i-Bo 10: 5-9.

- 2004. 'The Global Songs from Bonin: Origin and Dissemination of Offically Recognised Songs of the Ogasawara Islands.' In Musicology and Globalization: Proceedings of the International Congress in Shizuoka 2002, edited by Kanazawa Masakata, 472-75. Tokyo: Academia Music Ltd.

. 2005. "Ogasawaran Dancers" Encounter with Pacific Dancers: A Report from the 9th Pacific Festival of Arts in Palau.' In Refereed Chapters from the 1st International Small Island Cultures Conference, edited by Mike Evans, 99-107. Sydney: The Small Island Cultures Research Initiative.

—_.2008. 'Mikuroneshia ni okeru kōshin odori no odori-uta no ongaku teki tokuchō' ミクロネシアにおける行進踊りの踊り歌の音楽的特 徵 [The musical characteristics of the Micronesian marching dancesongs]. In Mikuroneshia, Ogasawara, Okinawa no Minzoku Geinō Köryū to Sono Juyō, Henka no Dōtai ni Kansuru Hikaku Kenkyū ミクロ ネシア、小笠原、沖縄の民俗芸能交流とその受容、変化の動態に 関する比較研究 [A comparative study of the performing arts being spread by cultural exchange between Micronesians, Ogasawarans, and Okinawans focusing on its reception and changing aspects], edited by Konishi Junko 小西潤子, 25-33, 89-94. Shizuoka: Shizuoka University. 
.2012. 'Nanyō odori ga monogataru rekishi-Ogasawara no chōetsusei to tabunka-sei’ 『南洋踊り』が物語る歴史一小笠原の超越性 と多文化性一 [The history narrated by Nanyō odori-Ogasawara's transcendency and multiculturalism]. In Nohon no Kokkyō MondaiGenba kara Kangaeru 国境」問題一現場から考える [Border issues of Japan—thinking from the sites), 354-65. Tokyo: Fujiwara Shoten.

Long, Daniel ダニエル・ロング. 2002. ed. Ogasawara gaku koto-hajime 小笠原学ことはじめ [The introduction of Ogasawara studies]. Kagoshima: Nanpō Shinsha.

Long, Daniel ダニエル・ロング, and Inaba Makotoc 稲葉慎編著. 2004. eds. Ogasawara handobukku 小笠原ハンドブック [Ogasawara handbook]. Kagoshima: Nanpō Shinsha.

Ministry of Land, Infrastructure, Transport, and Tourism of Japan 国土交 通省. 2003. Ogasawara Shotō no Shuyō Shihyō 小笠原諸島の主要指 標 [The major statistics of the Ogasawara Islands]. [Tokyo]. Accessed 12 September 2010. www.mlit.go.jp/crd/chitok/73/sankou.pdf.

Nora, Pierre. 1996. 'General Introduction: Between Memory and History.' In Realms of Memory: Rethinking the French Past-Volume 1: Conflicts and Divisions, edited by Lawrence D. Kritzman, 1-20. Translated by Arthur Goldhammer. New York: Columbia University Press.

Ohama Katsuhiko 大浜勝彦 and Machida Shozo 町田昌三編著. 1991. eds. Ogasawara Kodomo Kashū 小笠原子ども歌集 [Ogasawara children songbook]. Ogasawara: Ogasawara Elementary School.

Quin, Michael. 1856. 'Notes on the Bonin Islands.' Journal of the Royal Geographical Society of London 26: 232-35. doi.org/10.2307/1798359.

Shepardson, Mary. 1977. 'Pawns of Power: The Bonin Islanders.' In The Anthropology of Power: Ethnographic Studies from Asia, Oceania, and the New World, edited by Raymond D. Fogelson and Richard N. Adams, 99-114. New York: Academic Press.

__ 1998. 'The Bonin Islands: Pawns of Power.' Unpublished manuscript reserved in Menzies Library, The Australian National University. 
Shishikura, Masaya. 2014. 'Wanting Memories: Histories, Remembrances and Sentiments Inscribed in Music and Dance of the Ogasawara Islands.' PhD thesis, The Australian National University. hdl.handle. net/1885/11185.

— 2015a. 'The View from the Islands. Musical Crossing of the Ogasawara Islands.' The Newsletter (International Institute for Asian Studies) 71: 34-35.

—. 2015b. 'Transcending Musical Bodies: Embodiment of Multiple Bonds of the Ogasawara Islands.' Journal of Musical Science (Novosibirsk State Conservatoire) 4: 50-67.

Takayama Taeko 高山妙子. 1986. Nihon de Ichiban Töi Shima: Ogasawara ni Kurashite,75-'85 日本でいちばん遠い島:小笠原に暮らして '75-'85 [The farthest island in Japan: Life in Ogasawara, '75-'85]. Tokyo: Nishida Shoten.

Tanaka Hiroyuki 田中弘之.1997. Bakumatsu no Ogasawara: Ōbei no Hogei Sen de Sakaeta Midori no Shima 幕末の小笠原: 欧米の捕鯨 船で栄えた緑の島 [Ogasawara at the end of shogunate: The green islands flourished with whaling boats from the West]. Tokyo: Chūō Kōron Shinsha.

Wakazawa Mineo 若澤峰雄. 2003. 'Senzen Haha Jima Okimura no Minzoku Geinō’ 戦前母島沖村における民俗芸能 [The performing arts of pre-war Okimura, Haha Jima]. Self-complied booklet. 
This text is taken from A Distinctive Voice in the Antipodes: Essays in Honour of Stephen A. Wild, edited by Kirsty Gillespie, Sally Treloyn and Don Niles, published 2017 by ANU Press, The Australian National University,

Canberra, Australia.

dx.doi.org/10.22459/DVA.07.2017.08 